\title{
大学キャンパスにおける駐輪場の利便性評価に関する研究 一某技術系大学に拈けるケーススタデイー \\ A STUDY ON THE EVALUATION FOR CONVENIENCE OF PARKING SPACES IN A UNIVERSITY
}

- A case study in a university -

\author{
平賀 慎 ${ }^{*}$, 杉田 洋 ${ }^{* *}$, 村川三郎***, 近藤 貴 道**** \\ Makoto HIRAGA, Hiroshi SUGITA, Saburo MURAKAWA \\ and Takamichi KONDO
}

\begin{abstract}
A certain university's survey showed that the students' evaluation on the facilities environment on the campus depends on how much convenience the university provides for parking their bikes. In other words, all the university facilities are less appreciated only owing to the insufficient bike-parking areas. The purpose of this paper is to discuss several problems of the bike-parking areas with the students feel unsatisfied, and suggest some ideas of what the university should do for them. To begin with, we analyzed the answers which the students made to the questions we asked them about the bike-parking areas. Next, on the basis of that result we had the evaluation items by which we can measure the convenience of the bike-parking areas. Finally, the survey based on the evaluation items posed several problems to solve for the bike-parking areas.
\end{abstract}

Keywords : Campus FM, Convenience of Parking Spaces, Evaluation items, User satisfaction, Importance level キャンパスFM，駐輪場の利便性，評価項目，満足度，重要度

\section{1. 序}

現在、大学進学希望者数と入学定員が均衡する「全入時代」が到来 しており、各大学においては、「教育プログラムの見直し」「施設環境 の充実」といった「大学における総合評価の向上」に関する検討が進 められている。

しかしながら、社会的経済環境の低迷は大学の財政事情にも大きな 影響を与えており、特に「施設環境の充実」に久かせない施設管理業 務においては、事後保全的な姿勢から脱却し切れないのが現状である。

このような背景を受け、筆者ら ${ }^{112.2)}$ は、大学における総合評価の向 上」に関寸る諸施策のなかでも、「施設環境の充実」に着目し、学生に よる評価を施設整備および環境改善について検討するための指標と位 置づけた「施設環境評価手法」を提案している。また、某大学に対す る本手法の適用から、現在の施設環境のなかで学生に不満をもたらし ている要因の1つは「駐輪場の利便性」であることを明らかにしてい る。

大学における施設環境に関する研究、駐輪場に関する研究はこれま でにも行われている。

前者の研究として、山口ら ${ }^{3)}$ は、当時 95 の国立大学 170 キャンパス における施設管理者を対象として、施設環境に対する評価を求め、各 キャンパスの物的特性と評価との関倸について分析している。また、 岡田ら ${ }^{4) .5}$ は、施設利用者、管理者双方の合意形成に基づく施設整備
項目を設定し、「魅力的品質」「当たり前品質」といった品質認識を考 慮した满足度特性分析手法を提案している。さらに、そのほかの視点 から大学施設管理について論考した研究として、永峰ら ${ }^{8) .71}$ は、大学 キャンパスの施設管理における諸要因の関連分析をとおして施設管理 とキャンパス FM の現状把握を行っている。金ら ${ }^{8)}$ は、大学会館の整備 状況に着目し、施設整備特性に関する調查から、諸室の面檟および整 備に関する問題点を明らかにしている。また、櫻木ら ${ }^{9}$ は、当時の国 立大学における空間構成および使用形態と施設管理費の比較分析から、 費用負担は建物規模の大小よりも、むしろ利用頻度や用途により大き な影響を受けることを明らかにしている。

後者の研究として、鈴木ら ${ }^{10)}$ は、市街地における歩道上の駐輪に着 目し、将来の駐輪台数の予測式を作成したうえで、現在有効活用され ていないスペースに関する調查から、新たな駐輪スペースの提案を行 っている。また、田中ら ${ }^{11}$ は、安全な移動や駐輪スペースの有効利用 を妨げている「はみ出し駐輪」に着目し、駐輪場を有する施設におけ る利用者の行動調查から、はみ出し駐輪と施設利用特性の関連につい て分析を行っている。

しかしながら、大学キャンパスにおける駐輪場の利便性について、 利用者評価により論考した研究はみられない。

そこで本研究では、図1に示した大学施設環境管理フローに基づき、 大学キャンパスにおける駐輪場の利便性評価について検討寸る。以下

\footnotetext{
*NTTファシリティーズ 修士(工学)

** 広島工業大学環境学部 准教授・博士 (工学)

*** 広島大学大学院.工学研究科 教授・工博

**** 広島工業大学大学院・環境学研究科 大学院生
}

NTT Power and Building Facilities Inc., M. Eng.

Assoc. Prof., Faculty of Environmental Studies, Hiroshima Institute of Technology, Dr. Eng. Prof., Graduate School of Engineering, Hiroshima Univ., Dr. Eng.

Graduate Student, Graduate School of Environmental Studies, Hiroshima Institute of Technology 


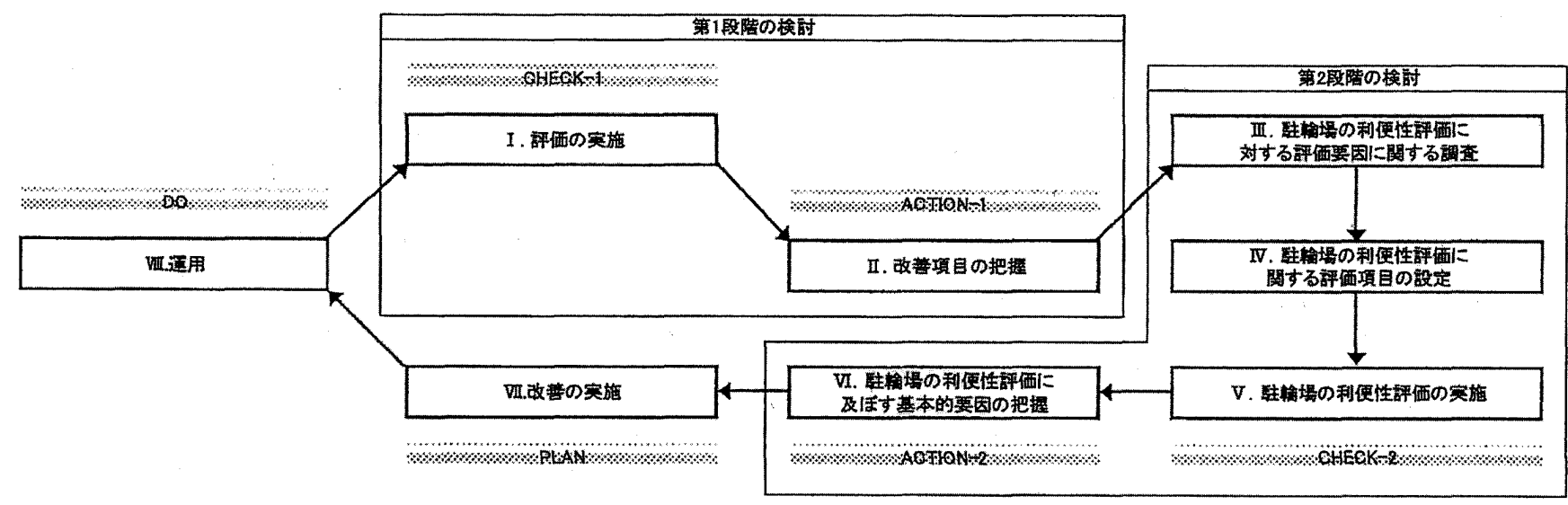

図 1 大学施設環境管理フロー

に大学施設環境管理フローにおける本研究の位置を示す。「施設環境 評価手法」の範囲は「PLAN」「DO」「CHECK」「ACTION」といったFMサイ クルのなかの「CHECK」、および「ACTION」に位置しており、本手法の 適用により、「PLAN」および「DO」の段階を円滑に実行するための知 見を得ることが目的である。

前述したように、筆者らは既往の研究 $\left.{ }^{11}{ }^{2}\right)$ において、本手法におけ る第 1 段階の検討から、改善項目の1つに駐輪場の利便性」があるこ とを明らかにしているが、「駐輪場の利便性」を評価するための評価項 目の設定には至っていない。

そこで本研究では、第 2 段階の検討として、「III. 駐輪場の利便性 評価に対する評価要因に関する調査」以降の分析を進め、「VII. 改善の 実施」段階において必要となる知見を得ることを目的とする。

具体的には、「III．駐輪場の利便性評価に対寸る評価要因に関寸る 調查」により学生が駐輪場の利便性を評価する際の着目点を明らかに したうえで、「IV. 駐輪場の利便性評価に関する評価項目の設定」を行 う。続いて、設定した評価項目を用いた $「 \mathrm{~V}$. 駐輪場の利便性評価の 実施」、および「VI. 駐輪場の利便性評価に及ぼす基本的要因の把挃」 から、現在の駐輪場の利便性に対して不満をもたらす基本的要因を明 らかにする。

以上のように、本研究では、利用者評価に基づいた大学キャンパス における駐輪場の利便性評価手法について検討するために、某技術系 大学に対してケーススタディを実施し、駐輪場の利便性評価に関する 基本的要因を明らかにする。

\section{2. 対象施設の概要}

对象施設は、既往研究 ${ }^{11.2)}$ において、「I．評価の実施」を行った某 大学キャンパスに整備されている11 箇所の駐輪場である。なお、大学 には約 4,400名（男性：4,104名、女性：275 名）の学生が在籍してお り注1)、その約半数が自転車または自動二輪車・原動機付自転車(以下、 「バイク」と記す）により通学している。

各駐輪場の配置を図 2 に示す。敷地一帯が南東向きの傾斜地であり、 自転車専用駐輪場は敷地南側、すなわち標高の低い側を中心に 5 筒所、 自動二輪車および原動機付自転車専用駐輪場 (以下、「バイク専用駐輪 場」と記す）は教地北側を中心に 6 箇所、それぞれ整備されている。 また、表1に示すように、各駐輸場の収容可能台数は自転車で計 1.610 台、バイクで計 651 台であり、自転車専用 5 箇所のうち 4 箇所、バイ ク専用 6 箇所のうち 3 箇所には屋根が設置されている。なお、バイク

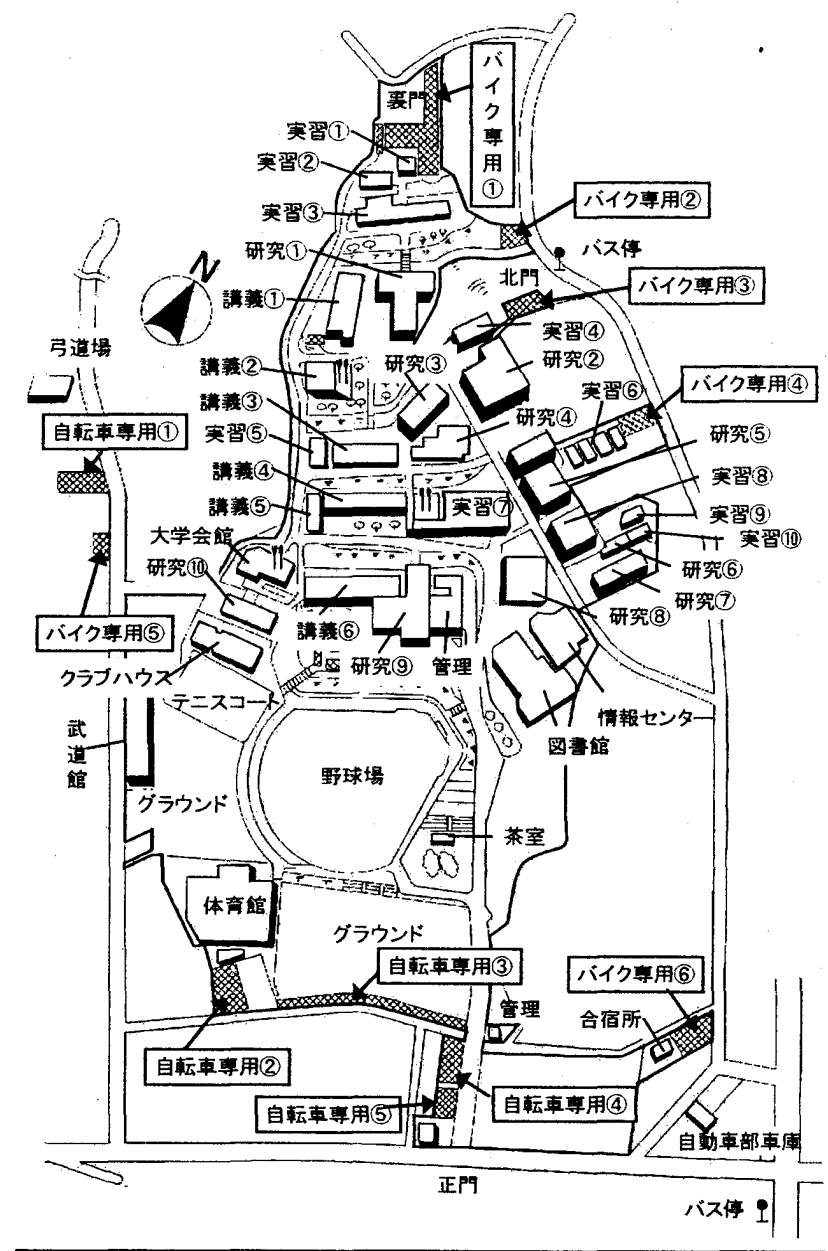

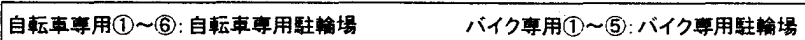

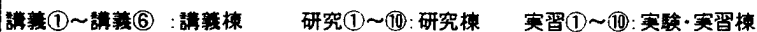

図 2 各駐輪場の配置

表 1 各駐輪場の概要

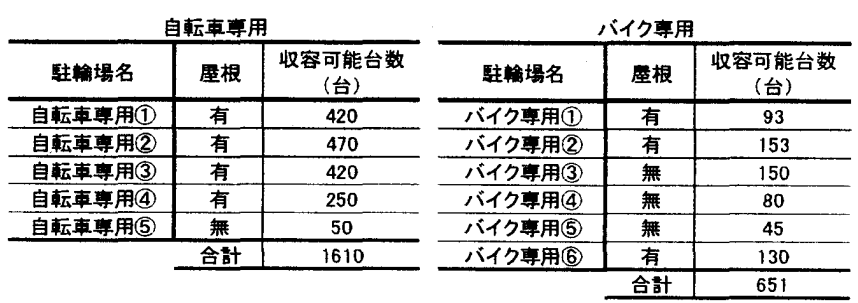


については、学科ごとに利用可能駐輪場が指定されている注2)。

各駐輪場における1日の駐輪状況は、大学管理者により2〜6回/日 の周期で記録されている注 3)。11 简所の駐輪場における時間帯別平均 駐輪台数を図 3 および図 4 に、年間最大駐輪台数記録時の天候、およ び駐輪台数を表 2 にそれぞれ示す注4)。

図 3 に示した自転車専用駐輪場では、自転車専用(1)、(2)を除き、1 日のピーク時間帯における平均駐輪台数が収容可能台数を上回ってい ることがわかる。なかでも、自転車専用(4)、(5)では、記録開始時刻で ある 9:00から既に収容可能台数を上回っており、ピーク時間帯には収 容可能台数の 150〜250\%の駐輪がみられる。

図 4 に示したバイク専用駐輪場の平均駐輪台数については、バイク 専用(4)、(5)において、記録開始時刻である 11:00から既に収容可能台 数を上回っており、ピーク時間帯には収容可能台数の $200 \%$ 超えてい る。一方、バイク専用(1)、(2)、(3)、(6)においては、1 日のピーク時間 帯でも収容可能台数の $50 \%$ 未満となっている。ここで、図 2 に示した 各駐輪場の配置をみるなら、バイク専用(5)講義(6)、講義(4)などの講 義棟、バイク専用(4)は研究(4)、研究(5)などの研究棟へのアクセスが容 易な場所に位置していることがわかる。さらに、表 2 に示した年間最 大駐輪台数記録時のデータによると、屋根を有寸るバイク専用(2)、(6) では、雨天に最大駐輪台数を記録しており、年間平均の $200 〜 300 \%$ の 駐輪がみられる。したがって、利用可能駐輪場の指定に関わらず、通 常時には講義棟または研究棟へのアクセスが容易な駐輪場へ、雨天に は屋根を有する駐輪場へ集中していることがわかる。

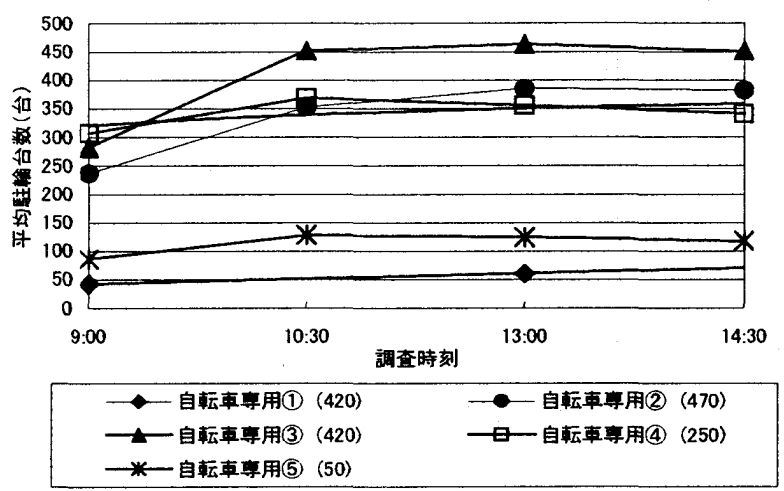

※( )内の值は、表1に示した各駐艋䭪の収容可能台数を指す

図 3 時間帯別平均駐輪台数 [自転車専用]

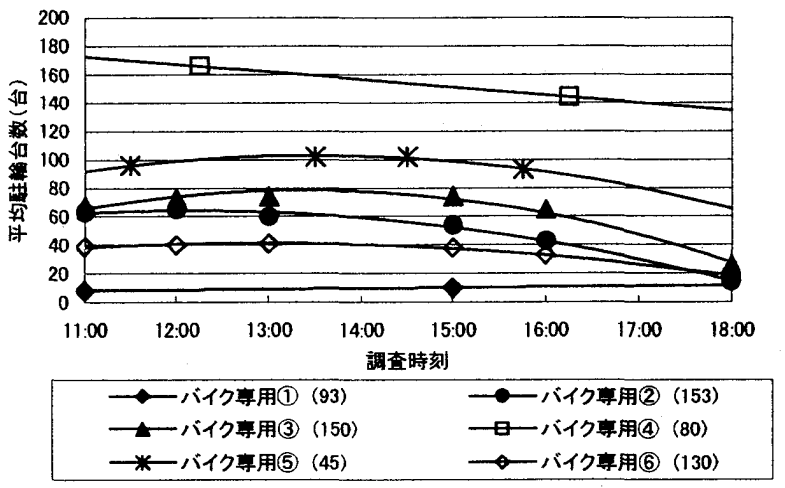

※( )内の值は、表1に示した各駐鍮場の收容可能台数を指す

図 4 時間帯別平均駐輪台数 [バイク専用]

\section{3. 評価項目に関する検討}

「III．駐輪場の利便性評価に対する評価要因に関する調査」から得 られた結果に基づき、学生による駐輪場の利便性を評洒する際の着目 点を把握したうえで、「IV.駐輪場の利便性評価に関する評価項目の設 定」を行う。

\section{1 調查概要}

\section{（1） アンケート調査の概要}

調查は、2005 年 12 月中旬、対象大学の建築系学科に所属する学生 145 名を対象に調查票を配布し、その場で回収した注5)。なお、有効回 答数は 125 票である。

アンケートの内容は、大別して「便利な駐輪場の条件に関する質問」 「個人特性に関する質問」の 2 グループで構成される。

（a）「便利な駐輪場の条件に関する質問」学生が駐輪場の利便 性を評価する際の着目点を把握するため、回答者自身の考える「便 利な駐輪場の条件」について、自由記述形式で回答を求める。

（b）「個人特性に関する質問」回答者属性（性別・学年・学科） についてそれぞれ回答を求める。

\section{（2）回答者属性}

回答者属性を表 3 に示す。対象大学に在籍寸る学生全体の男女比(約 9.4:0.6) と比較して女性の割合が若干高くなっているが、男性の割合 が 8 割を超えている。なお前述したように、本調查は学年および学科 を限定して行っているため、「学年」は概放 3 年生、「学科」は建設工 学科および環境デザイン学科のみとなっている。また、図 2 における 各学科の所属建物は、それぞれ建設工学科が研究(8、環境デザイン学 科が研究(5)であるが、ゼミに配属されるまでの 1 年生から 3 年生前期 までは、主に講義(6)を心に行動していることを別途実施した調査に より明らかにしている。

\section{2 評洒要因の把握}

自由記述で得られた「便利な駐輪場の条件」の 321 の指摘を分類・ 集計するにあたり、まず、記述表現が曖昧なものに対して、対象大学 に在籍する学生 2 名の合議により簡単な表記の統一を行った結果、こ れら 321 の指摘は 31 種類で表現された。続いて、これら 31 種類の指 摘を $\mathrm{KJ}$ 法により、「A：駐輪場設備」「B:立地」「C:広さ」「D：管理」の 4 つに分類した注 6 。分類ごとの集計結果を表 4 に示す。

これより、「駐輪場に屋根がある」「講義室に近い場所にある」とい った指摘が特に多く、約 5 割の回答者により指摘されていることがわ

表 2 年間最大駐輪台数記録時の概要

\begin{tabular}{|c|c|c|c|c|}
\hline 駐輪場名 & 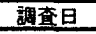 & 天侯 & 触套時刻 & 駐鈴台数 (台) \\
\hline 自転車亭用(2) & 4月18日 & 暗れ & $9: 00$ & 530 \\
\hline 自転車算用(3) & 4月12日 & 睛れ & $13: 00$ & 665 \\
\hline 自転車軎用(4) & 5月16日 & 晴れ & $10: 30$ & 464 \\
\hline 自転車連用(5) & 6月12日 & 晴れ & $13: 00$ & 180 \\
\hline \multirow{2}{*}{ バイク章用(1) } & 4月11日 & 睛れ & $15: 00$ & \multirow{2}{*}{18} \\
\hline & 5月31日 & 踣れ & $15: 00$ & \\
\hline バイク毫用(2) & 9月20日 & 雨 & 12.00 & 117 \\
\hline バイク㪣用(3) & 4月14日 & 睛れ & $16: 00$ & 141 \\
\hline ハイイク毫用(4) & 10月26日 & 晴れ & $16: 15$ & 252 \\
\hline バイク亭用(5) & 11月21日 & 晴れ & $13: 30$ & 135 \\
\hline バイク寻用(6) & 4月13日 & 雨 & $12: 00$ & 125 \\
\hline
\end{tabular}

表 3 回答者属性

\begin{tabular}{|c|c|c|c|c|c|}
\hline アイテム & カテゴリー & サンプル数 & アイテム & カテゴリー & サンプル数 \\
\hline \multirow{2}{*}{ 性別 } & 男性 & 102 & \multirow{2}{*}{ 学科 } & 建設工学科 & 63 \\
\hline & 女性 & 23 & & 理境デザイン学科 & 62 \\
\hline \multirow[t]{2}{*}{ 学年 } & 3年生 & 122 & & & \\
\hline & 4年生 & 3 & & & 単位: \\
\hline
\end{tabular}


かる。また、漠然とした「C:広さ」に関する内容、「防犯対策ができて いる」についても多くの指摘が得られた。

\section{3 評価項目の設定}

ここでは、前節で明らかにした「便利な駐輪場の条件」に基づき、 図 1 に示した「IV，駐輪場の利便性評価に関寸る評価項目の設定」を 行う。

表 4 に示した「便利な駐輪場の条件」のうち、漠然とした指摘を除 き、同様の対策によって改善できる内容を表すものを統合した 20 項目 を対象に表現を一部修正し、評価項目を設定した。さらに、A〜Dの各 分類における総合評価に関する項目をそれぞれ追加した。設定した評 価項目を表 5 に示す。

\section{4. 駐輪場の利便性評価に関する検討}

表 5 に示した評価項目を用いて「V．駐輪場の利便性評価の実施」 を行い「現状に対する満足度」および「駐輪場の利便性を評価するう えでの重要度」に関する分析から、改善が必要となる駐輪場を明らか にしたうえで、駐輪場の利便性評価を低下させている「基本的要因」 を明らかにする。

\section{1 調查概要}

\section{(1)‘ヒアリング調査の概要}

調查は、2006 年 7 月下旬、1 日の平均駐輪台数が著しく少ない「バ イク専用(1)」お゙よび「自転車専用(1)」を除く9䉪所において、駐輪場 を利用する学生を対象に面接形式により実施した注7)。有効回答数は各 駐輪場で 30〜50 票、合計 397 票である。ヒアリングの内容は、「現状 に対する満足度」「駐輪場の利便性を評価するうえでの重要度」「個人 特性に関する質問」の 3 グループの設問で構成し、6 頁 32 項目からな る。
(a)「現状に対する満足度」
表 5 に示した各評価項目について、
「不満である」「やや不満である」「どちらともいえない」やや 満足である」「満足である」の 5 段階で回答を求める。

表 4 「便利な駐輪場の条件

\begin{tabular}{|c|c|c|c|}
\hline 分類 & 指摘内容 & 指摘数 & th \\
\hline \multirow{6}{*}{ 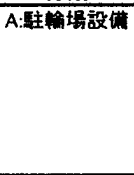 } & 䒠增場に座根がある & 77 & \multirow[t]{6}{*}{107} \\
\hline & 防犯対策ができている & 21 & \\
\hline & 照明設供がある & 6 & \\
\hline & 駐輪場が建物内にある & 1 & \\
\hline & 駐諭場の出入り口の数が多い & 1 & \\
\hline & 段差がない & 1 & \\
\hline \multirow{12}{*}{ B:立地 } & 讙䓪室に近い場所にある & 62 & \multirow[t]{12}{*}{85} \\
\hline & ぜミ室に近い場所にある & 3 & \\
\hline & 坂道を登らなくてよい & 3 & \\
\hline & クラプハウスに近い坦所にある & 1 & \\
\hline & 体伺馆に近い場所にある & 1 & \\
\hline & 雨の日に軎戠室まで濡れずに行ける & 1 & \\
\hline & 笨内にある & 2 & \\
\hline & 建物に直銡されている & 1 & \\
\hline & 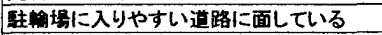 & 2 & \\
\hline & 敖地入り口に近い場所にある & 2 & \\
\hline & 樓内に入りやすい道にある & 1 & \\
\hline & 莫然と㷂蜼に関する指摘をした内容 & 6 & \\
\hline \multirow[t]{4}{*}{ c:広さ } & 駐䇶スペースが広い & 19 & \multirow[t]{4}{*}{76} \\
\hline & 强堬場の出入り口が厇い & 6 & \\
\hline & 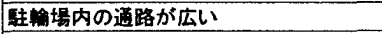 & 4 & \\
\hline & 漠然と広さを指墒した内容 & 47 & \\
\hline \multirow[t]{10}{*}{ D:管理 } & 一台分の駐軨スペースが区画されている & 6 & \multirow[t]{8}{*}{25} \\
\hline & 媑輪場が学科ごとに指定されている & 4 & \\
\hline & 整理整頓されている & 6 & \\
\hline & 安全である & 3 & \\
\hline & 㴋潔㦛がある & 1 & \\
\hline & 近縢への配虚が為されている & 2 & \\
\hline & 土やほこりが飛んでこない & 1 & \\
\hline & 漠然と管理に関する指婹をした内容 & 2 & \\
\hline & その他漠然とした内容 & 28 & 28 \\
\hline & 合計 & 321 & 321 \\
\hline
\end{tabular}

（b）「駐輪場の利便性を評価するうえでの重要度」現在使用して いる駐輪場の状況に関わらず、駐輪場の利便性を評価する際、表 5 に示した各評価項目がどの程度重要なのか、重要でない「あまり 重要でない「どちらともいえない」やや重要である」「重要であ る」の 5 段階で回答を求める。

（c）「個人特性に関寸万質問」回答者属性（性別・学年・学科· 課外活動・駐輪場の選択理由）についてそれぞれ回答を求める。な お、駐輪場の選択理由については、「設備が整っている」「目的の施 設に近い「広い「適切に管理されている」に「その他」を加えた 5 項目より回答を求める。また、選択理由が「目的の施設に近い」 の回答者に対しては、「講義室」「ゼミ室」「クラブハウス」「体育 館」「その他」から目的の施設について回答を求める。

（2）回答者属性

回答者属性を表 6 に示す。性别では、「男性」が 9 割以上を占め、学 年では「3 年生」の割合が若干高くなっている。駐輪場の選択理由で は、「目的の施設に近いが 6 割以上を占め、「広い」といった回答も 1 割程度みられた。目的の施設としては、「講義室」「ぜミ室」が多く 举げられている。

\section{2 各評洒項目に対する重要度の把握}

各評価項目に対する重要度を把握するため、駐輪場ごとに重要度の 表 5 駐輪場の利便性に関する評価項目

\begin{tabular}{|c|c|c|}
\hline 分類 & 評価項目 & 略돌 \\
\hline \multirow[t]{7}{*}{ A:駐愈場設傅 } & 駐軨スペースに痤根がある & A1 \\
\hline & 防犯設備がある & A2 \\
\hline & 照明設菕がある & A3 \\
\hline & 駐而場が建物内にある & A4 \\
\hline & 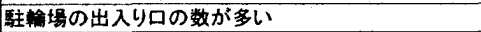 & A5 \\
\hline & 駐輸場出入りロに段差がない & A6 \\
\hline & 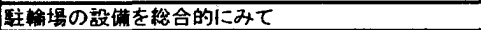 & $\overline{\mathrm{Ag}}$ \\
\hline \multirow[t]{7}{*}{ B:立地 } & 偝英室に近い場所にある & B1 \\
\hline & ぜミ室に近い場所にある & 82 \\
\hline & 歩いて坂道を登らなくてよい場所にある & B3 \\
\hline & クラブハウスに近い場所にある & 84 \\
\hline & 体育館に近い䭪所にある & 85 \\
\hline & 雨の日に目的の施設まで濡れずに行ける垣所にある & 86 \\
\hline & 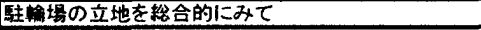 & $\mathrm{Bg}$ \\
\hline \multirow[t]{4}{*}{ C:広さ } & 駐輅スペースが広い & C1 \\
\hline & 駐输場の出入り口が広い & $\mathrm{C} 2$ \\
\hline & 駐輪場内の通路が広い & C3 \\
\hline & 宔輪場の広さを轱合的にみて & $\mathrm{Cg}$ \\
\hline \multirow[t]{6}{*}{ D:管理 } & 一台分の駐骦スベースが区画されている & D) \\
\hline & 駐輍䭪が学科ごとに指定されている & $\mathrm{D} 2$ \\
\hline & 自転車・バイクが整理されている & D3 \\
\hline & 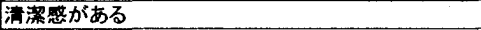 & D4 \\
\hline & 近滕への配虑が為されている & D5 \\
\hline & 恇輸場の管理を総合的にみて & $\mathrm{Dg}$ \\
\hline
\end{tabular}

表 6 回答者属性

\begin{tabular}{|c|c|c|c|c|c|}
\hline アイテム & カテゴリー & $n$ & アイテム & カテゴリー & $n$ \\
\hline \multirow{2}{*}{ 性別 } & 男性 & 372 & \multirow{10}{*}{ 学科 } & 電子・光シスデム工学科 & 30 \\
\hline & 女性 & 25 & & 電気・デイジタルシスデム工学种 & 45 \\
\hline \multirow{6}{*}{ 学年 } & 1年生 & 92 & & 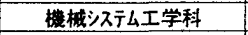 & 73 \\
\hline & 2年生 & 78 & & 知能機械工学科 & 25 \\
\hline & 3年生 & 130 & & 建築工学科 & 19 \\
\hline & 4年生 & 90 & & 情報工学科 & 13 \\
\hline & 大学院生 & 6 & & 知的倩報システム学科 & 49 \\
\hline & 研究生 & 1 & & 棵境デザイン学科 & 88 \\
\hline \multirow{2}{*}{ 裸外活動 } & 所蚛している & 167 & & 建設工学科 & 28 \\
\hline & 所榐していない & 230 & & その地 & 27 \\
\hline \multicolumn{6}{|c|}{ 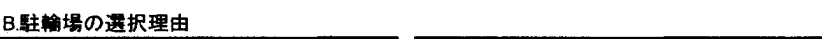 } \\
\hline アイテム & カテゴリー & $n$ & アイテム & カテゴリー & $n$ \\
\hline \multirow{5}{*}{ 䡆択理由 } & 設備が整っている & 15 & \multirow{5}{*}{ 目的施設 } & 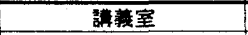 & 168 \\
\hline & 目的の施設に近い & 253 & & ゼミ室 & 85 \\
\hline & 広W & 44 & & クラプハウス & 28 \\
\hline & 逜切に管理されている & 6 & & 体育館 & 11 \\
\hline & その他 & 79 & & その他 & 2 \\
\hline
\end{tabular}


平均評価得点を算出した注8)。自転車専用、バイク専用それぞれの平均 評価得点プロフィールを図 5 に示す。なお、図中の「Ag」「Al」といっ た目盛ラベルは表 5 右欗に示した各評価項目の略号を示す。

これより、Ag〜Dgに示した各分類における総合的重要度については、 各駐輪場ともに、各分類とも 4.0 前後の值を示している。したがって、

「A：駐輪場設備」「B:立地」「C:広さ」「D：管理」のいずれも駐輪場の 利便性を評価するうえで重要であるといえる。また、A1～D5 の各評価 項目に対寸る重要度は、自転車専用、バイク専用ともにほぼ同様の傾 向を示していることがわかる。さらに仔細にみるなら、自転車専用、 バイク専用とも「Al:駐輪スペースに屋根がある」「Bl:講義宝に近い場 所にある」「Cl:駐輪スペースが広い」といった項目に対する重要度が 高く、「B3:歩いて坂道を登らなくてよい場所にある」「B4:クラブハウ スに近い場所にある」「D2:駐輪場が学科ごとに指定されている」とい った項目に対する重要度は低い傾向がみられた。

ここで、駐輪場間における重要度の評価傾向を把握するため、各評 価項目に対寸る重要度の平均評価得点により相関係数を算出した。結 果を表 7 に示す。

同表より、自転車専用同士では $0.82 \sim 0.94$ 、バイク専用同士でも $0.69 \sim 0.88$ の強い相関を示すことがわかる。また、「自転車専用」と 「バイク専用 $」$ 相互においても $0.65 \sim 0.92$ と比較的強い相関を示して いる。したがって、駐輪場の利便性を評価するうえでの重要度は、自 転車とバイクの違い、および現状の整備状況の違いによって差異がみ られないといえる。
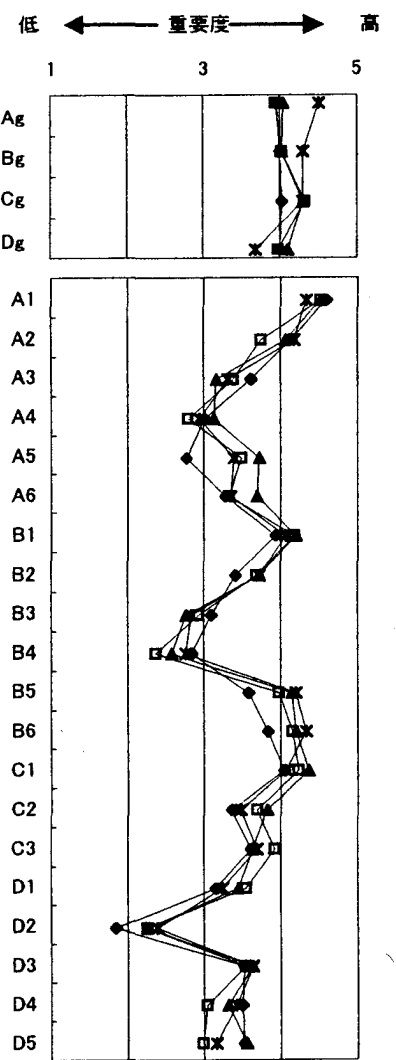

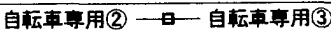

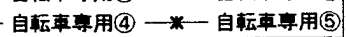

図 5 重要度の平均評価得点プロフィール

\section{3 「要改善施設」の把握}

ここでは、満足度および重要度により、現在、学生に不満をもたら している駐輪場（以下、「要改善施設」と記す）を把握する。

各駐輪場における総合的な満足度を把捏するため、式(1)により、総 合満足度得点を算出した注 9 。 結果を図 6 に示す。

$\mathrm{Sd}_{\mathrm{p}}=\left\{\Sigma\left(\mathrm{S}_{\mathrm{Di}} \cdot \mathrm{I}_{\mathrm{i}}\right)-\sum\left(3 \cdot \mathrm{I}_{\mathrm{i}}\right)\right\} /\left\{\Sigma\left(5 \cdot \mathrm{I}_{\mathrm{i}}\right)-\sum\left(1 \cdot \mathrm{I}_{\mathrm{i}}\right)\right\} \cdots(1)$

ここで、各駐輪場における総合満足度得点について、つぎのように 記号を定める。

$\mathrm{Sd}_{\mathfrak{D}}$ : 各駐輪場における総合満足度得点

$\mathrm{S}_{\mathrm{pi}}$ : 各評価項目に対する満足度の平均評価得点 i 10$)^{2}$

$I_{\mathrm{i}}$ : 各評価項目に対する重要度の平均評価得点の 9 筒所における平 均値

p，i はそれぞれ駐輪場、評価項目を表す。なお、4 分類における 総合評価 $(A g \sim D g)$ は分析より除く。

図 6 に示寸総合満足度得点において、自転車専用(2)が最も高い值を 示し、バイク専用(4)、(5)において特に低い值を示している。この結果 と、表 1 に示した各駐輪場の概要、および図 4 に示した平均駐輪台数 を併せてみるならば、バイク専用(4)、(5)は、いずれも屋根が設置され ておらず、駐輪台数は収容可能台数を大きく上回っていることがわか る。

本研究では、满足度の平均評価得点がすべて 3（どちらともいえな い）となった場合の総合満足度得点 0 を基準として、0 未満の值を示 した駐輪場を「要改善施設」と定義する。したがって、自転車専用で は、自転車専用(3)、(4)、(5)の 3 籄所、バイク専用では、バイク専用(3)、 (4)、(5)の 3 筒所、計 6 箇所を以降の分析対象とする。

\section{4 評価に及ぼす「基本的要因」の把握}

ここでは、前節で明らかにした 6 筒所の「要改善施設」に対する、 満足度と重要度の関連分析から、学生に不満をもたらす「基本的要因」 を明らかにする。図 7 に、满足度を横軸、重要度を縦軸にとり、各評 価項目における両評価の平均評価得点を布置した。ここでは例として、

表 7 駐輪場間における重要度の相関係数

\begin{tabular}{|c|c|c|c|c|c|c|c|c|c|}
\hline & \multicolumn{4}{|c|}{ 自転車夏用 } & \multicolumn{4}{|c|}{ バイク毫用 } \\
\hline & & (2) & (3) & (4) & (5) & (2) & (3) & (4) & (5) \\
\hline \multirow{3}{*}{ 自転事草用 } & (3) & 0.82 & & & & & & & \\
\hline & (4) & 0.83 & 0.94 & & & & & & \\
\hline & (5) & 0.87 & 0.93 & 0.94 & & & & & \\
\hline \multirow{5}{*}{ バイク車用 } & (2) & 0.84 & 0.88 & 0.91 & 0.91 & & & & \\
\hline & (3) & 0.65 & 0.79 & 0.79 & 0.81 & 0.78 & & & \\
\hline & (4) & 0.73 & 0.92 & 0.89 & 0.88 & 0.80 & 0.75 & & \\
\hline & (5) & 0.66 & 0.87 & 0.84 & 0.77 & 0.74 & 0.80 & 0.87 & \\
\hline & (6) & 0.77 & 0.77 & 0.80 & 0.84 & 0.88 & 0.76 & 0.71 & 0.69 \\
\hline
\end{tabular}
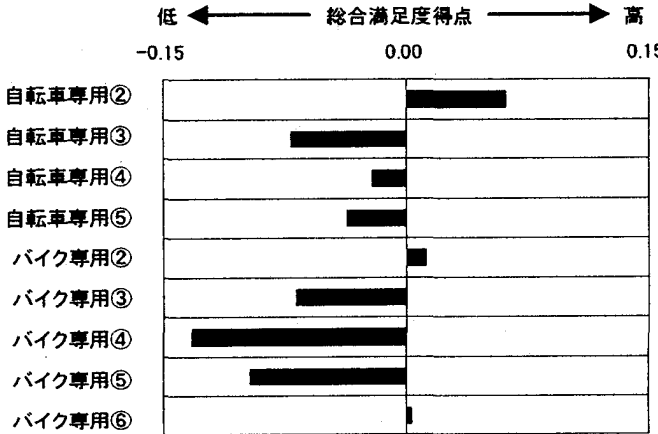

図 6 総合満足度得点 
バイク専用(4)の結果を示す。なお、 4 分類における総合評価 $(\mathrm{Ag} \sim \mathrm{Dg})$ は分析より除いた。

図中で示した一点鎖線は、各評価項目における満足度、または重要 度の平均評価得点を平均したものであり、全体の平均から各評価項目 の位置づけを判断するための基準と捉えることができる。すなわち、 満足度、重要度それぞれの平均ラインにより分割された 4 象限は、右 上から逆時計回りに第 1 象限「20項目のなかでも相対的に満足度・重 要度が共に高い、第 2 象限「相対的に満足度が低く、重要度が高い」、 第 3 象限「相対的に満足度・重要度が共に低い小第 4 象限「相対的に 满足度が高く、重要度が低い」という意味をもつ。ここでは、この象 限区分における各評価項目の位置づけから、改善が必要な項目を検討 するが、本研究では、改善を実施した際にその効果が顕著に認められ る第 2 象限に位置する項目を駐輪場の利便性評価に及ぼす「基本的要 因」と定義する。

表 8 に、6 筒所の「要改善施設」にて指摘された「基本的要因」を それぞれ示す。

最も多く指摘された項目は、「B6:雨の日に目的の施設まで濡れずに 行ける場所にある」であり、すべての「要改善施設」をとおして指摘 されている。また、「C2:駐輪場の出入り口が広い「「C3:駐輪場内の通 路が広いりについても、6 施設中 5 施設で指摘されていることがわか る。

自転車専用とバイク専用の違いに着目するなら、「A1 :駐輪スペース に屋根がある」は、いずれも屋根の設置されていないバイク専用 3 筒 所すべてにおいて指摘されているが、自転車専用のなかでも屋根の設 置されていない自転車専用(5)では指摘されていないといった違いがみ られる。また、「B1:講義室に近い場所にある」「B2:ゼミ室に近い場所 にある」「B3:歩いて坂道を登らなくてよい場所にある」は自転車専用 3 筒所すべてにおいて指摘されているが、バイク専用では指摘されて いないといった違いがみられた。このことは、図2に示したように、 自転車専用駐輪場忙自転車による登坂を避けるため、敷地の南側に多 く設置されていることから、講義棟、研究棟など目的の施設への距離 が長くなったことに起因していると考えられる。

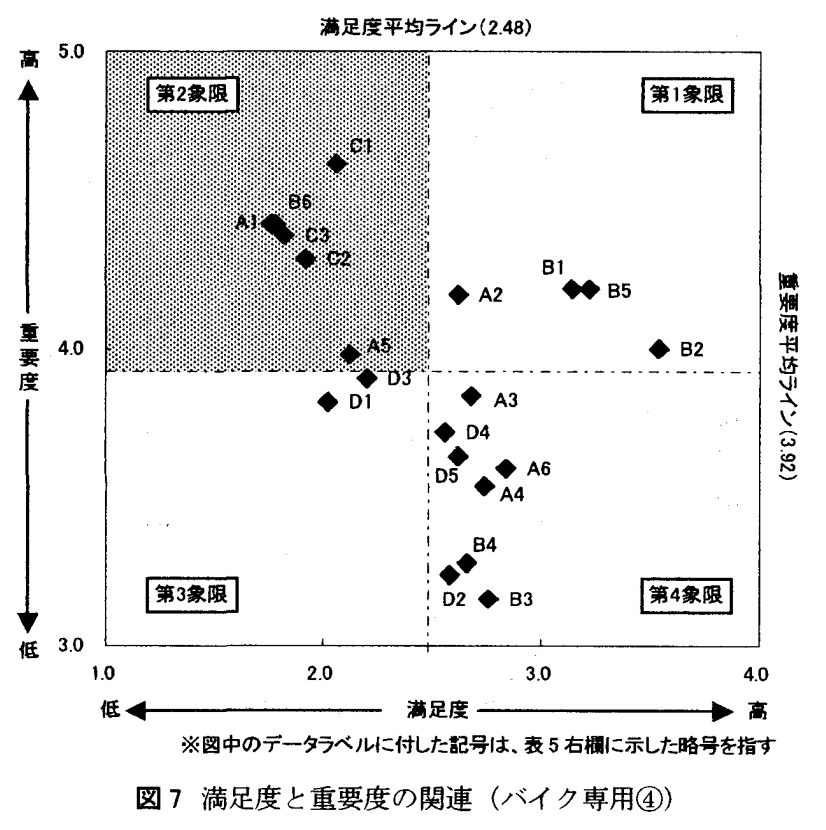

$-136-$

\section{5. 結語}

本研究では、学生による評価を施設整備および環境改善について検 討するための指標と位置づけた「施設環境評価手法」の導入に向けた ケーススタディの一睘として、「駐輪場の利便性」に着目し、図、に示 した大学施設環境管理フローにおける「III. 駐輪場の利便性評価に対 する評価要因に関する調査」以降の検討を進め、学生に不満をもたら している「基本的要因」を明らかにした。

まず、学生の自由記述により得られた「便利な駐輪場の条件」に基 づき、駐輪場の利便性に関する 24 の評価項目を設定した。続いて、評 価対象である 9 簓所の自転車もしくはバイク駐輪場それぞれについて、 それぞれの利用者を対象に、各評価項目に対する満足度および重要度 による利便性評価を求め、その結果より算出した総合満足度得点から、

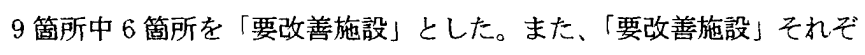
れについて満足度と重要度の関連分析を行い、駐輪場の利便性に対寸 る評価を低下させている「基本的要因」を明らかにした。

「要改善施設」である 3 籄所の自転車専用駐輪場では、「B1: 講義室 に近い場所にある」「B2:ゼミ室に近い場所にある」「B3:歩いて坂道を 登らなくてよい場所にある」がすべての駐輪場において、評価を低下 させている「基本的要因」として指摘された。このことは、自転車専 用駐輪場は自転車による登坂を避けるため、橎地の南側に多く設置さ れていることから、講義棟、研究棟など目的の施設一の距離が長くな ったことに起因していると考えられる。

また、「要改善施設」である 3 箇所のバイク専用駐輪場では、いずれ も屋根が設置されていないことから、すべての駐輪場において「A1： 駐輪スペースに屋根がある」が評価を低下させている「基本的要因」 上して指摘された。

さらに、すべての自転車専用駐輪場とバイク専用駐輪場において、 $\lceil\mathrm{B} 6$ : 雨の日に目的の施設まで濡れずに行ける場所にある」は、評価を 低下させている「基本的要因」として指摘された。

以上、ケーススタディで得られた成果を示したが、本研究の主題は、 大学キャンパスにおける駐輪場の利便性評価手法について検討するこ とにある。本研究では、ケーススタディとして某大学に対して本手法 を適用することにより、駐輪場の利便性を評洒するうえで学生が何を 重視し、どこに不満を抱いているのか、その基本的要因を明らかにし た。

ここで本手法を発展させるために必要となる今後の展開について述 ベる。

駐輪場は、一般的に敷地周辺部に配置されるケースが多く、近隣住 民からの苦情が絶えない施設である。本研究においても一部の駐輪場 で、「D5: 近隣への配慮が為されている」といった項目が評価を低下さ せている「基本的要因」として指摘されていることから、本研究によ る知見をベースとして、近隣住民などの駐輪場利用者以外に対しても

表 8 評価に及ぼす「基本的要因」

\begin{tabular}{|c|c|c|c|c|c|c|c|}
\hline \multirow[b]{2}{*}{ No. } & \multirow{2}{*}{ 項目 } & \multicolumn{3}{|c|}{ 自坛覃南用 } & \multicolumn{3}{|c|}{ ハイク軎用 } \\
\hline & & (3) & (4) & (5) & (3) & (4) & (5) \\
\hline $\mathrm{A} 1$ & 駐䑳スペースに屋根がある & & & & 0 & 0 & O \\
\hline A2 & 防犯設偀がある & 0 & & & 0 & & \\
\hline A5 & 住軨场の出入り口の数が多い & & & & & 0 & \\
\hline B1 & 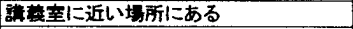 & 0 & 0 & 0 & & & \\
\hline B2 & ゼミ䒧に近い堪所にある & 0 & 0 & 0 & & & \\
\hline B3 & 歩いて坂道を登らなくてよい場所にある & 0 & 0 & 0 & & & \\
\hline B6 & $\begin{array}{l}\text { 雨の日に目的の施設まで海れずに行け } \\
\text { る場所にある }\end{array}$ & 0 & 0 & 0 & 0 & 0 & 0 \\
\hline C1 & 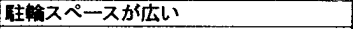 & & 0 & 0 & & 0 & 0 \\
\hline $\mathrm{C} 2$ & 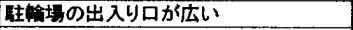 & 0 & $\mathrm{O}$ & & $\mathrm{O}$ & 0 & $\mathrm{O}$ \\
\hline $\mathrm{C} 3$ & 朢䑳场内の通路が広い & $\mathrm{O}$ & 0 & 0 & & 0 & 0 \\
\hline D1 & 一台分の尉錀スペースが区画されている & 0 & & & & & $\mathrm{O}$ \\
\hline D5 & 近陡への配盧が為されている & & & & 0 & & \\
\hline
\end{tabular}


駐輪場に関する評価を求める必要がある。また本研究では、利用者が 著しく少ない駐輪場（「自転車専用(1)」「バイク専用(1)」)を評価対象か ら除いている。本来ならば、このような駐輪場の改善案を検討する上 で必要となる知見を示すことが重要であると考えられる。しかしなが ら、利用者評価により評価を低下させている「基本的要因」を明らか にする本手法においては、利用者が著しく少ない対象の評価は困難で ある。この点については、学生による認識の有無、利用されていない 要因に関寸る調査を別途実施し、今後検討を重ねる必要がある。

\section{謝辞}

調査研究に多大なご協力をいただいた調査対象大学の学生の方々に 謝意を表します。また本研究は、広島工業大学 2006 年度卒論生、岡田 裕一郎君に協力いただきました。ここに謝意を表します。

注

注 1）学生数は、2005 年 5 月 1 日現在のデータである。

注 2）各駐輸場における学科指定は、バイク専用(1) : 電気・ディジタルシステム 工学科、バイク専用(2) : 機械システム工学科・知能機械工学科、バイク専 用(3) : 建設工学科・環境デザイン学科、バイク専用(4)：環境情報学科、バ イク専用(5): 主にクラブ活動等、バイク専用(6) : 電子・光システム工学科・ 知的情報システム工学科となっている。

注 3）それぞれの駐輸場において記録時刻、記録回数に違いがあるが、これは大 学側が限られた記録員を巡回させていることによる。

注 4）分析には、自転車専用では 2004 年 11 月〜2005 年 10 月、バイク専用では 2004 年 4 月〜2005 年 3 月の休業日老除く平日に測定したデータを用いてい る。

注 5)ここでは、駐輸場利用者・非利用者を問わず、幅広い意見を取り入れるた め、坊輸場利用の有無は求めず、アンケートを行っている。

注 6) 本研究では、安心感等の心理的要素も「利便性」を評価する一評価軸であ ると判断している。

注 7)「自転車専用(1)」は、2006 年 7 月下旬の調查期間において、利用者がほと んどみられなかったため、調查対象より除いた。

注 8）重要度の平均評価得点を算出するにあたり、「重要でないる1点、「あま り重要でないを 2 点、「どちらともいえない」を 3 点、「やや重要である」 を 4 点、「重要である」を 5 点に得点化した。

注 9）式(1)は、文献12)に扔る「満足度得点に基つく渵足度ウェイトの算定」 考考考としている。なお、文献 12) における渵足度得点は、充足度得点（满 足度の平均評価得点）と重要度得点（重要度の平均評価得点）との積であ る。したがって、ここでは、満足度得点の 20 項目での総和を各駐輸場にお ける総合満足度得点と定義した。なお、総合満足度得点の基泩を示すため、

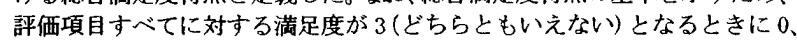

最大值と最小值のレンジが 1 となるように変換している。また、 4.2 節で 述べたように、重要度は、自転車とバイクや、整偏状況の違いによって差 異がみられないことから、重要度得点として、重要度の平均評洒得点の 9 筒所での平均值を用いた。

注 10）満足度の平均評伍得点を算出するにあたり、「不満である」を1点、「や や不満である」を 2 点、「どちらともいえない」を 3 点、「やや満足である」 を 4 点、「渵足である」を 5 点に得点化した。

\section{参考文献}

1) 平賀慎，杉田洋，村川三郎，近藉貴道：大学における FM 管理手法に基づいた 施設境境評価们関する研究その 1 施設環境評価手法の概要および調查概要, 㻴境の管理, No. 56, pp. 33-36, 2005. 10

2）平賀慎，杉田洋，村川三郎，近藤贵道：大学における FM管理手法に基ついた 施設環境評価に関する研究その 2 問題項目の抽出および属性が重要度に及 ぼす影響，環境の管理、No. 56，pp. 37-40，2005.10

3）山口勝已, 谷口汎邦, 高野文雄 : 国立大学キャンパスにおける施設・環境に 関する評価と物的特性, 日本建筑学会計画系論文集, No. 560, pp89-96,2002. 10

4）岡田真幸，位奇和久，下田貞幸，大西康伸：異なる梘点を持つ参加主体に上 る大学施設整備項目の重要度算定手法に関する研究，日本建築学会計画系論 文集, No. 593, pp. 79-85, 2005.7

5）風田真幸，位寄和久，下田賁幸，大西康伸，岡秀和：キャンパス整備計画策 定のための施設整偏項目の満足度特性分析手法に関する研究，日本建築学会 計画系論文集，No.601，pp.65-71，2006.3

6）永峰章 : 大学キャンパスの施設管理に関する調查研究一第 4 報 国公立大学 の概要一, 日本建筑学会大会学術講演梗概集，D-1 冊，pp607-608，1997.9

7) 水崇章 : 大規模施設の施設管理に関す万調查研究一その 1 研究概要と大学 キャンパスの FM 評価一, 日本建築学会大会学術講演梗概集, F-1 冊, pp. 1363-1364, 2004.8

8）金鍾石, 宫本文人, 志水英樹, 石田 真 : 国立大学における大学会館の諸室 構成と整借特性に関する研究, 日本建築学会計画計論文集, No. 478, pp. 79-88, 1995 年 12 月

9）櫻木邦浩, 藍澤宏，草原麻衣子 : 国立大学に扮汁るキャンパス内建物の空間 構成と使われ方からみた施設管理に関する研究, 日本建築学会計画系論文集, №. 593, pp. $49-55,2005.7$

10）鈴木政之, 寺内美紀子: 市街地駐輸分布特性からみた駐輸スペースの提案一 水戸中心市街地を事例として一, 日本建築学会大会学術講演梗概集, F-1 冊, pp. $649-650,2006.9$

11) 田中慶, 藤井晴行: 駐輸場からのはみ出し駐輸がなされる状況の調查, 日本 建筑学会大会学術講演梗概集，E-1 冊，pp. 961-962，2003.9

12）内閣府国民生活番議会総合企画部会.”生活満足指数（LSI）の総合化に用い る「満足度ウェイト」の算定方法についで.暮らし指数唡討委員会 (第 1 回) 資料 8. 内閣府国民生活番議会, 2002. (オンライン),

$\langle$ ht tp://www5. cao. go. jp/seikatsu/shingikai/kikaku/kurashishisuu/1127/sir you8. pdf〉, (参照 2007-2-03). 